\title{
EMIGRATION RAIDS BY SLAVE-MAKING ANTS: A RAPID-TRANSIT SYSTEM FOR COLONY RELOCATION (HYMENOPTERA: FORMICIDAE)
}

\author{
By Ellen C. Kwait ${ }^{1}$ and Howard TopofF ${ }^{2}$
}

\section{INTRODUCTION}

Polyergus lucidus Mayr is an obligate slave-making ant, found throughout north temperate regions of the world. Their slave raids are dramatic events in which columns of highly aroused workers penetrate nests of the related ant genus Formica, and carry the target colony's pupae back to their own nest (Marlin 1969; Talbot 1967). Although many of these pupae are consumed, varying numbers are reared through eclosion and become permanent members of the mixed-species nest. During the evolution of social parasitism, Polyergus workers lost the ability to participate in the ordinary chores of foraging, nest maintenance, and brood rearing, all of which are left to the Formica slaves.

Raiding behavior in Polyergus has only been reported in the context of slave raids, or of intraspecific territorial raids (Topoff et al. in preparation). Field observations of colonies in late summer, however, have revealed an entirely new function of raiding behavior: the rapid transport of colony members during emigrations to new nests at the end of the slave-raiding season. During such colony movements, the low level of mixed-species ant traffic is periodically interrupted by the abrupt emergence of Polyergus workers, and their formation into a well-organized swarm. The Polyergus workers promptly "raid" the old nest, and transport adult Formica individuals to the new site. For such group processes, occurring in the context of nest relocation, we propose the term "emigration raid."

\footnotetext{
'Department of Biology, City College of CUNY, New York, N.Y. 10031.

2Department of Psychology, Hunter College of CUNY, New York, N.Y. 10021, and The American Museum of Natural History, New York, N.Y. 10024 Manuscript received by the editor May 28, 1983.
} 


\section{Methods}

Emigration raids were observed in three mixed colonies of $P$. lucidus and $F$. schaufussi Mayr, located in a pine-barrens habitat in North Centereach, Long Island, N.Y. The most detailed data were collected from a colony monitored continuously from July through September, 1976. The emigrations occurred on September 19 and 20 , as the colony moved to a previously-constructed nest, $5.9 \mathrm{~m}$ southwest of the old site. Movements of individual ants shuttling between nests were monitored with hand-held tally counters. Callow age was estimated by comparing their degree of pigmentation with individuals of known age in laboratory nests (Kwait 1982).

\section{RESUlts AND Discussion}

During the morning and early afternoon of each day, the population characteristics of the emigrations were similar to those described for Polyergus nest movements that occasionally occur in the spring (Marlin 1971). Thus, only Formica workers functioned as transporters, carrying adults and brood of both species to the winter nest (Fig. 1). As the afternoon progressed, however, several P. lucidus workers periodically joined the emigration. Although these Polyergus individuals made 5-23 trips between nests, the important point to note is the relatively low level of overall activity during most of the afternoon (Fig. 2A). But starting about $1600 \mathrm{hrs}$ (EDT), at approximately the same time as the onset of slave raids earlier in the season (compare Fig. 2A and 2B), groups of 30-69 callow and mature- adult Polyergus abruptly surged out of the new nest and formed into an organized swarm. This raid swarm backtracked and penetrated the old nest, and after several minutes the Polyergus workers emerged carrying nestmates (Table 1). On both emigration days, the first emigration raid was promptly followed by a second raid (Fig. 2A). Activity levels for both species then dropped abruptly, as they typically do during slave raids on freeliving colonies of Formica.

Aside from our field observations on emigration raids, the only other reference to Polyergus carrying adult Formica individuals is Huber's (1810) study in Switzerland, of an emigration into an abandoned Formica nest. A more recent observation of comparable behavior stems from studies of $P$. breviceps-Formica gnava mixed colonies in a desert habitat in southeastern Arizona (Topoff et al. in 


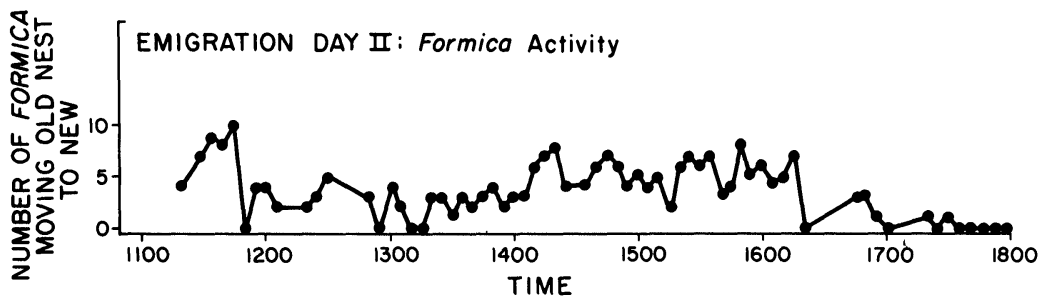

Figure 1. Activity of Formica schaufussi during colony emigration. Most of the workers are carrying adults and brood of Polyergus and Formica to the winter nest.

preparation). On August 14, 1981, colony $\# 1$ raided another mixed nest (\#2), $30 \mathrm{~m}$ to the east. Fighting between resident and intruding Polyergus workers was minimal, and only about 11 pupae were captured. Early in the afternoon on August 15, Polyergus workers emerged from colony \#2 and backtracked over the previous day's trail towards mixed colony \#1. At 1715 hrs (MST), traffic again reversed direction, as hundreds of Polyergus workers penetrated nest \#2. This time, however, the Polyergus emerged carrying hundreds of Formica brood, callows, and mature-adult individuals. All of the adult Formica being transported had their appendages closely appressed to the body, in the "pupa-like" position that is typical during social carrying behavior (Möglich and Hölldobler 1974). The adult Formica were carried into mixed nest \#1, and none had re-emerged by the end of the observation period at sunset.

The description by Huber (1810) of adult Formica transport by Polyergus clearly took place within the context of a colony emigration. Our observation of similar behavior by P. breviceps is more difficult to interpret, but we suggest that it occurred in the context

Table 1. Quantitative Description of Emigration Raids

\begin{tabular}{cccccc}
\hline Date & Raid \# & Time & $\begin{array}{c}\text { Polyergus } \\
\text { on raid }\end{array}$ & $\begin{array}{c}\text { Adult Formica } \\
\text { retrieved }\end{array}$ & $\begin{array}{c}\text { Formica pupae } \\
\text { retrieved }\end{array}$ \\
\hline \multirow{3}{*}{$9 / 19 / 76$} & 1 & 1525 & 56 & 37 & 3 \\
& 2 & 1625 & 45 & 35 & 0 \\
$9 / 20 / 76$ & 1 & 1620 & 69 & 30 & 0 \\
& 2 & 1703 & 30 & 15 & 0 \\
\hline
\end{tabular}


of colony reunification shortly after division by budding. The important point in both cases, however, is that adult transport of Formica by Polyergus took place in a staggered, prolonged, emigration-type column, without the intervention of an abrupt, shortlived, and full-scale raid.

That the $P$. lucidus emigration raids reported in the present study are fundamentally similar behavioral processes to their slave raids is evidenced by the congruence of several parameters, including: (1) the immediate organization of the emerging workers into an organized swarm; (2) the time of raid onset; (3) the occurrence of multiple raids; and (4) the participation of recently-eclosed Polyergus callows. The number of Polyergus workers in the emigration raids was lower than that characteristic of most slave raids. This difference is probably not significant, because it is known that even slave-raid participants decrease to as few as 13-50 individuals towards the end of the raiding season (Talbot 1967). Nevertheless, the social context of an emigration does produce at least one major difference in the behavior of the Polyergus workers. During emigration raids, it is principally Formica adults that are carried by the Polyergus. Because these adult slaves were reared from the pupal stage in the chemical and tactile environment of the mixed nest, the communicatory basis for social carrying behavior is well established. During slave raids, by contrast, Formica adults respond to the intruding Polyergus by exhibiting various forms of withdrawal behavior (Wilson 1971). As a result, it is principally Formica pupae and callows that are retrieved during slave raids.

Emigration behavior with adult transport is common in many ant species (Smallwood 1982), including free-living colonies of Formica schaufussi. Because $F$. schaufussi is considered related to Polyergus, emigrations probably pre-date the evolution of slave-raiding behavior. The secondary use of raiding behavior for Polyergus colony relocation represents an adaptive evolutionary transition, consistent with Simpson's (1958) principle of "transformation." Accordingly, when changes at any level of organization take place during a species' evolution, previously existing adaptations are often remodeled and eventually serve new functions. Because group raiding in Polyergus involves a complex recruitment process specialized for the efficient retrieval of other ants, it is clearly advantageous for the colony to utilize the process in all appropriate behavioral contexts. 

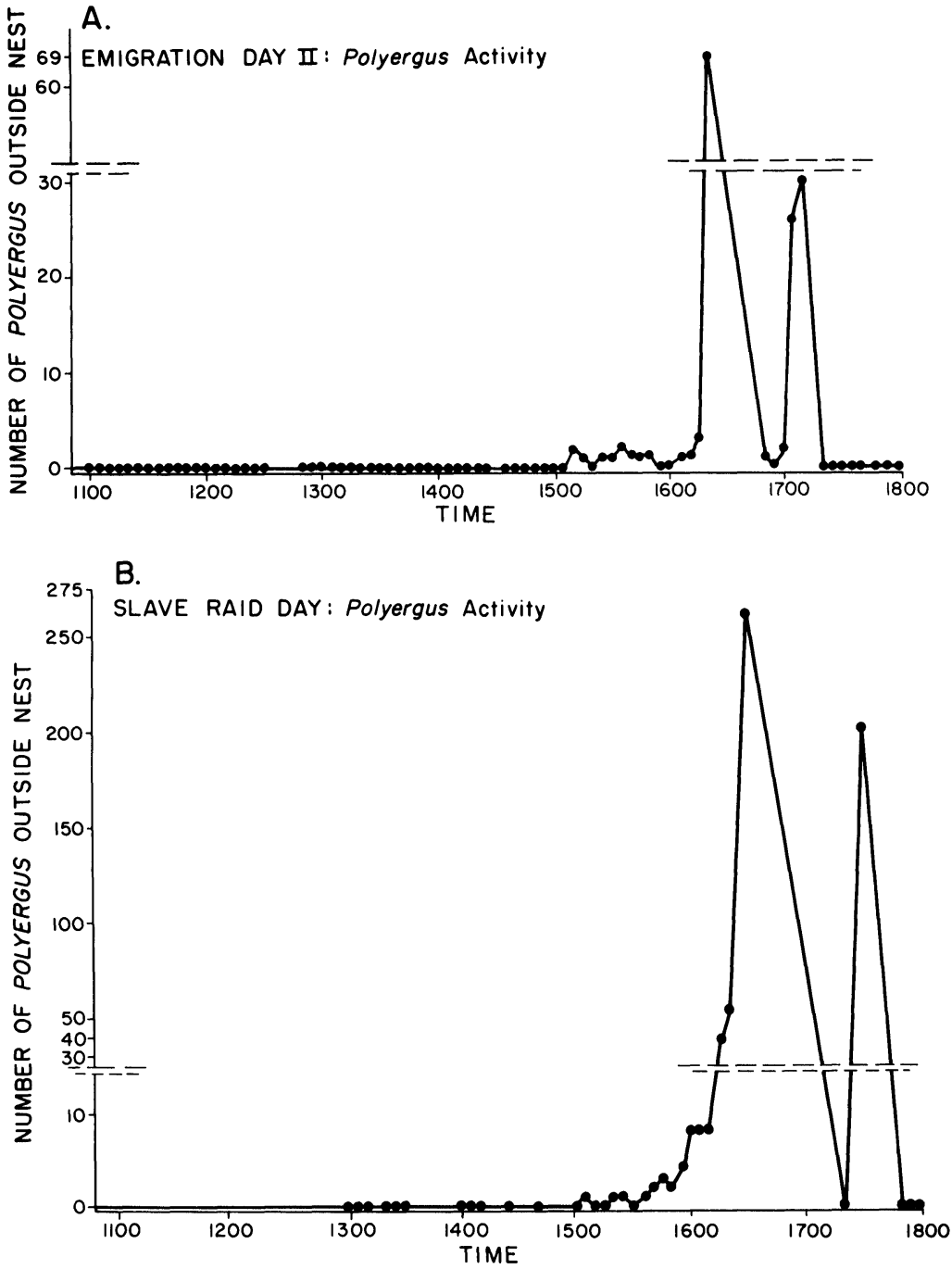

Figure 2. (A) Activity of Polyergus lucidus during colony emigration. The two consecutive peaks in afternoon activity represent emigration raids conducted on the old nest by Polyergus workers that were transported to the new nest by Formica individuals. (B) Activity of $P$. lucidus during typical slave-raid day. Note the similarity in timing of slave raids and emigration raids. 
The rapid transport by Polyergus of adult Formica slaves to an overwintering site shortens the emigration time during a season characterized by increasingly unfavorable weather, and quickly relocates the Formica slaves to the new nest where they are needed for overall colony maintenance.

\section{ACKNOWLEDGMENTS}

This study is part of a dissertation by the senior author, submitted to the graduate faculty in Biology of the City University of New York. The research was supported by NIMH Training Grant 14280 . Special thanks go to Mr. Raymond Sanwald for his field assistance.

\section{REFERENCES}

Huber, $P$.

1810. Recherches sur les moeurs des fourmis indigenes. J. J. Paschoud, Paris. KWAIT, E.

1982. Raid site location, recruitment, and polyethism in the slave-making ant Polyergus lucidus Mayr. Ph.D. thesis, City University of New York.

MarLin, J. C.

1969. The raiding behavior of Polyergus lucidus in central Illinois (Hymenoptera: Formicidae). J. Kansas Entomol. Soc. 42: 108-115.

1971. The mating, nesting, and ant enemies of Polyergus lucidus Mayr. Amer. Mid. Nat. 86: 181-189.

MOGLICH, M. AND B. HOLLDOBLER

1974. Social carrying behavior and division of labor during nest moving in ants. Psyche 81: 219-236.

Simpson, G. G.

1958. The study of evolution: methods and present status of theory. In A. Roe and G. G. Simpson, eds., Behavior and evolution. Yale University Press, New Haven, Conn. pp. 7-26.

SMALLWOOD, J.

1982. Nest relocation in ants. Insectes Sociaux 29: 138-147.

TALBOT, M.

1967. Slave raids of the ant Polyergus lucidus. Psyche 74: 299-313.

TOPOFF, H., B. LAMON, AND L. GoOdLOE

1983. Behavioral ecology of the western slave-making ant Polyergus breviceps. (in preparation)

WILSON, E. O.

1971. The Insect Societies. Belknap Press of Harvard University Press, Cambridge, Mass. 

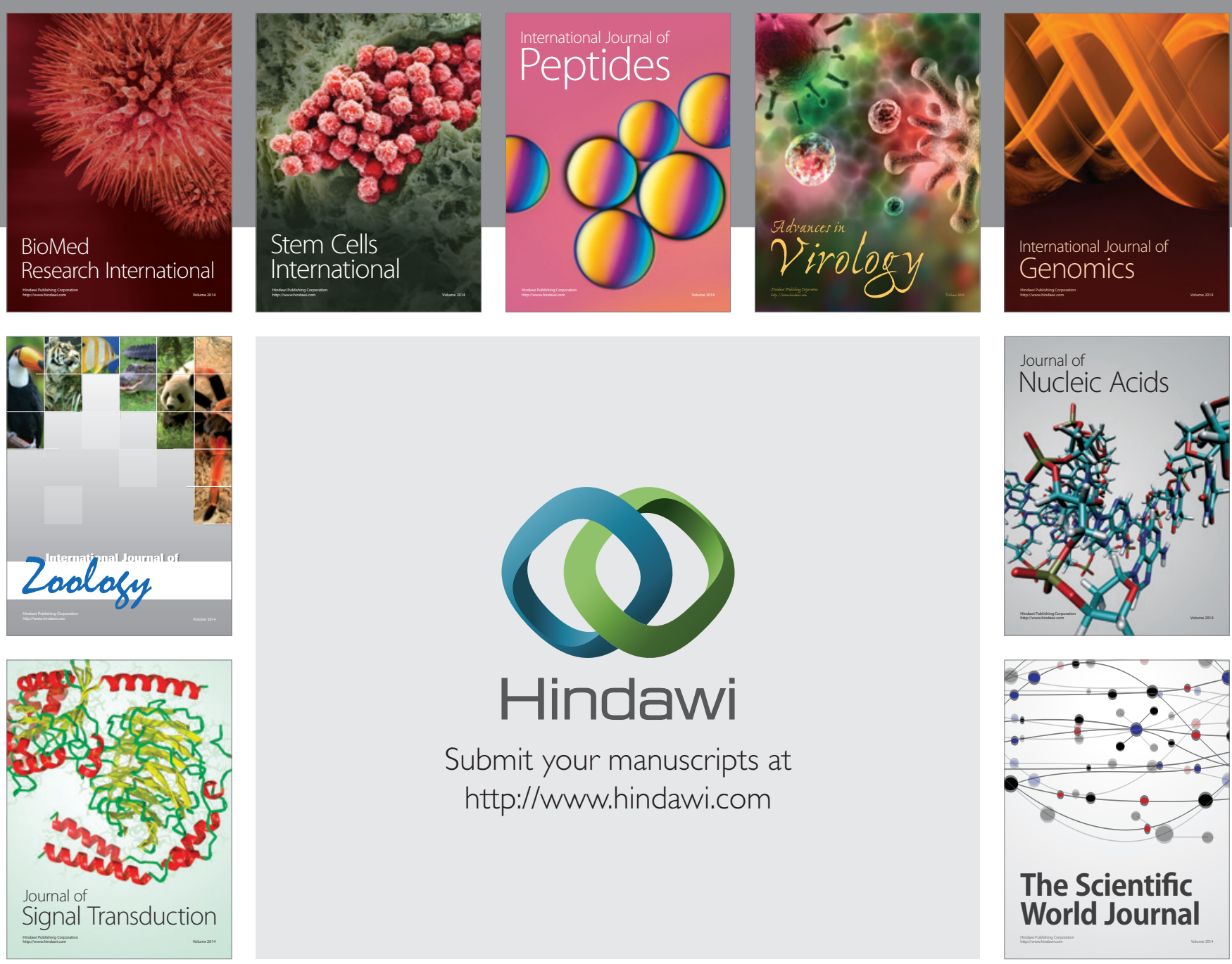

Submit your manuscripts at

http://www.hindawi.com
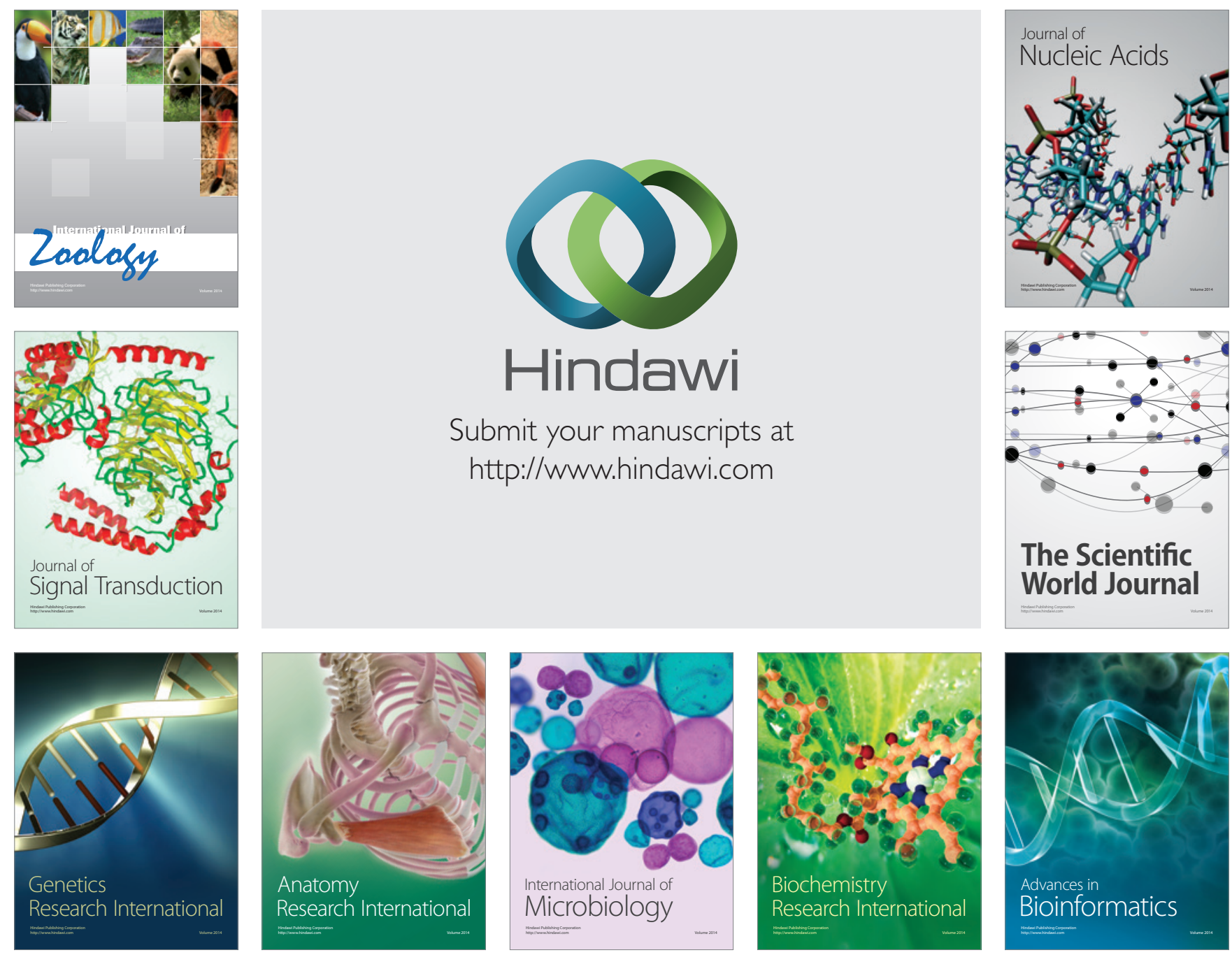

The Scientific World Journal
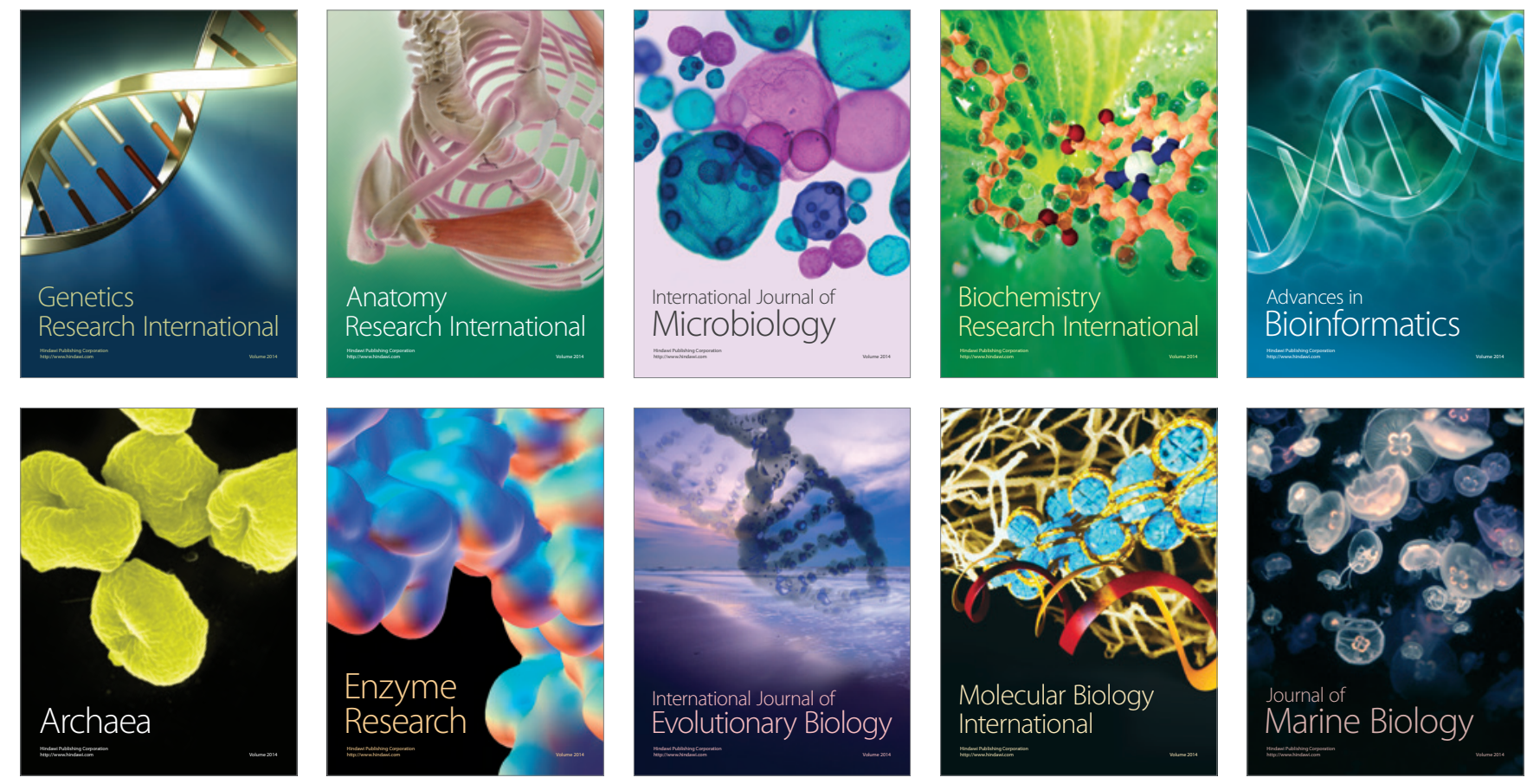